\title{
Efficacy and safety of rupatadine fumarate in the treatment of perennial allergic rhinitis: A multicenter, double-blinded, randomized, placebo-controlled, bridging study in Koreans
}

\author{
Tae-Bin Won, ${ }^{1,2}$ Hyung Gu Kim, ${ }^{3}$ Jeong-Whun Kim, ${ }^{1}$ Jin Kook Kim, ${ }^{4}$ Young Hyo Kim,,${ }^{5}$ Soo Whan Kim, ${ }^{6}$ Hyo Yeol Kim, ${ }^{7}$ \\ Dae Woo Kim, ${ }^{8}$ Sung Wan Kim, ${ }^{9}$ Chang-Hoon Kim, ${ }^{10}$ Chae-Seo Rhee ${ }^{2}$
}

\begin{abstract}
Background: The efficacy of rupatadine for the treatment of AR has been confirmed in numerous clinical studies, however there are very few studies on asian patients.

Objectives: To assess the safety and efficacy of rupatadine fumarate in the treatment of Korean perennial allergic rhinitis (PAR) patients.

Methods: A multicenter, double-blind, randomized, placebo-controlled, comparative study of rupatadine fumarate and bepotastine besilate was conducted. Each group was administered rupatadine, bepotastine or placebo for 4 weeks. Primary parameters for efficacy included morning and evening symptom reduction from baseline at 4 weeks. Treatment safety and tolerability were evaluated according to a self-reported incidence and type of adverse events at each follow up visit.
\end{abstract}

Results: Rupatadine showed a significant reduction in symptoms at morning and evening evaluations, in both 5 TSS $(-5.69, P<0.0006)$ and 4 NTSS $(-4.74, P<0.0015)$ compared to placebo. There was a significant reduction from baseline for 5TSS $(-65.4 \%, P=0.002)$ and 4 NTSS $(-63.7 \%, P=0.003)$ with rupatadine compared with placebo. At evening evaluations, there were significant reductions of 5TSS $(-63.2 \%, P=0.009)$ and 4 NTSS $(-61.6 \%, P=0.013)$ for the rupatadine group. Compared with bepotastine, rupatadine showed greater reduction in the morning symptoms at 4 weeks. When individual symptoms were assessed with 12-hour reflective mean daily symptom score, rupatadine showed better efficacy than placebo in sneezing $(P=0.016)$ and rhinorrhea $(P=0.097)$. The rate of adverse events showed no statistical significance.

Conclusion: Rupatadine is a safe and effective treatment option for Korean PAR patients and possibly a better choice over bepotastine for controlling morning symptom.

Key words: Perennial Allergic rhinitis, Platelet-activating factor, Histamine antagonists, TNSS, Randomized controlled trial, Clinical trial

From:

Department of Otorhinolaryngology-Head \& Neck Surgery, Seoul National University Bundang Hospital, Seongnam, Korea

Department of Otorhinolaryngology-Head \& Neck Surgery, Seoul National University Hospital, Seoul, Korea

Department of Otorhinolaryngology-Head \& Neck Surgery, Hanyang University Guri Hospital, Guri, Korea

4 Department of Otorhinolaryngology-Head and Neck Surgery, College of Medicine, Konkuk University, Seoul, Korea

Department of Otorhinolaryngology, Inha University, Incheon, Korea
6 Department of Otolaryngology-Head and Neck Surgery, Seoul St. Mary's Hospital, College of Medicine, The Catholic University of Korea, Seoul, Korea Department of Otorhinolaryngology, Samsung Medical Center, Seoul, Korea

8 Department of Otorhinolaryngology, Seoul National University Boramae Medical Center, Seoul, Korea

9 Department of Otorhinolaryngology, Kyunghee University Hospital, Seoul, Korea

${ }^{10}$ Department of Otorhinolaryngology, Yonsei University College of Medicine, Seoul, Korea 
Corresponding author:

Chae-Seo Rhee

Department of Otorhinolaryngology-Head \& Neck Surgery,

Seoul National University Bundang Hospital, Seongnam, Korea

Gumi-dong 300, Bundang-gu, Seongnam-si, Gyeonggi-do, Korea

E-mail: csrhee@snu.ac.kr

\section{Introduction}

Allergic rhinitis (AR) is a highly prevalent disease that markedly affects the quality of life. ${ }^{1,2}$ The current pharmacologic treatment strategies for AR include antihistamines, decongestants, leukotriene modifiers, and intranasal corticosteroids. The symptoms of AR are associated with the release and production of various mediators of the allergic response. Oral antihistamines are an effective first-line treatment for relief of symptoms such as itching, sneezing, and rhinorrhea. ${ }^{3}$ Although the primary mediator of the early reaction is histamine, other mediators have been recognized to contribute to the intricate allergic reaction. Among these, platelet-activating factor (PAF) has recently been found to be a robust chemo-attractor of eosinophils and a mediator of vasodilatation, playing a major role in the manifestation of the delayed allergic response. ${ }^{4,5}$

Rupatadine is an $\mathrm{N}$-alkyl pyridinium derivative that has recently been shown to possess both antihistamine and anti-PAF activity. ${ }^{6}$ The efficacy of rupatadine for the treatment of AR has been confirmed in numerous clinical studies. ${ }^{7,8}$ Since then, rupatadine has been approved for the treatment of seasonal and perennial AR and urticaria in the European Union and Russia. It is also approved in most Central and South American countries. ${ }^{9}$ Although clinical trials have shown definite benefits of rupatadine in the treatment of seasonal and perennial AR, these trials were limited to local subjects in the Western Hemisphere. Regional and ethnic variations among populations may alter a pharmaceutical compound's safety, efficacy, or dose response. ${ }^{10}$ To address the ethnic sensitivity of a drug in a new region, a bridging study can be conducted in the said region to "build a bridge" with foreign clinical data.

The present clinical study was conducted as a bridging study to assess the safety and efficacy of rupatadine fumarate in the treatment of Korean perennial allergic rhinitis (PAR) patients. Furthermore, the efficacy of rupatadine fumarate was compared to that of bepotastine, which is known to be safe and effective in treating AR. ${ }^{11}$

\section{Methods \\ Study design}

This was a multicenter, randomized, double-blind, placebo-controlled, comparative study of rupatadine fumarate $12.8 \mathrm{mg}$ (rupatadine $10 \mathrm{mg}$ ) and bepotastine besilate $20 \mathrm{mg}$ (reference drug). Each randomized group was administered rupatadine, bepotastine, or placebo (placebo of rupatadine or bepotastine) for 4 weeks. In the test group, a rupatadine $10 \mathrm{mg}$ tablet and a placebo bepotastine tablet were administered in the morning and a placebo bepotastine tablet was administered in the evening. In the control group, the placebo rupatadine tablet was administered in the morning and the placebo bepotastine tablet was administered in the evening.
In the reference group, the placebo rupatadine tablet and a bepotastine $10 \mathrm{mg}$ tablet were administered in the morning and the bepotastine $10 \mathrm{mg}$ tablet was administered in the evening.

A total of nine Korean tertiary centers participated in the trial. The trial began on August 26, 2013, and ended on July 1, 2016. The trial complied with the guidelines of local ethics committees, Good Clinical Practice guidelines, and local clinical trial regulations. All patients provided written informed consent before being included in the study. Each subject was randomized to the $\mathrm{A}, \mathrm{B}$, or $\mathrm{C}$ group in accordance with the predetermined randomization codes. The ratio of inclusion in each group was $1: 1: 1$. The randomization table was designed by statisticians using SAS 9.1 (SAS Institute Inc, Cary, NC), whereby each subject was sequentially assigned a random number (for inclusion in group $\mathrm{A}, \mathrm{B}$, or $\mathrm{C}$ ) by the randomization program. To ensure double-blinding, both placebo rupatadine and placebo bepotastine tablets were packaged in indistinguishable capsules. For each group, random codes were assigned and managed only by a clinical trial pharmacist appointed by the principal investigator and remained confidential until the end of the clinical study. If disclosure of a certain code was necessary due to a serious adverse event, only the relevant code was disclosed.

\section{Approval of the clinical study protocol}

Appropriate institutional review board approvals were obtained from the respective institutions.

\section{Inclusion and exclusion criteria}

Korean patients aged 12 years or older, with a diagnosis of PAR for at least 12 months, and with a total nasal symptom score (TNSS) of $\geq 5$ were included in this study. Patients were considered for inclusion in the study if they tested positive in a skin prick test for perennial allergens (diameter of the wheal, $>3 \mathrm{~mm}$ compared to that associated with saline control or greater than or equal to that associated with a histamine control at a concentration of $10 \mathrm{mg} / \mathrm{mL}$ ) during a screening visit or within 1 year before inclusion. The allergens related to PAR included house dust mites, cat and dog hair, mold, and cockroaches. A normal ECG was documented at the screening visit with the following requirements: QTc < $430 \mathrm{msec}$ for male patients and QTc $<450 \mathrm{msec}$ for female patients. Women of childbearing age were required to provide a negative pregnancy test and use adequate contraceptive measures during the study.

Patients with non-allergic rhinitis (vasomotor, infectious, or drug-induced rhinitis) were excluded. Patients with a history of treatment with nasal decongestants (in the previous 24 h); oral antihistamines, cold remedies, or disodium cromoglycate (in the previous week); ketotifen (in the previous month); topical antihistamines (previous $48 \mathrm{~h}$ ); or systemic or topical treatment with corticosteroids (except for topical hydrocortisone, $1 \%$ ), immunosuppressants, or any investigational drug within 2 weeks prior to inclusion were excluded. Other relevant exclusion criteria included abnormal laboratory values of clinical significance; a history of acute asthma within the previous 3 months; obstructive nasal polyps; or severe nasal 
septum deformity or hypersensitivity to compounds structurally related to the study drug. Patients who participated in another clinical study within 1 month of the present study were also excluded.

\section{Evaluation of efficacy}

During day 1 day 28, each subject filled in his/her patient diary every morning (within $1 \mathrm{~h}$ of awakening and prior to dosing) and evening (at the 12-h point after treatment in the morning) to record their nasal symptom scores within $12 \mathrm{~h}$ (reflective NTSS) and right before treatment (instantaneous NTSS). Severity scores for four nasal individual AR signs/ symptoms (rhinorrhea, sneezing, nasal itching, and nasal obstruction) and one ocular symptom were recorded on a scale of $0-3$ with a score of $0=$ absent, $1=$ mild, $2=$ moderate, and $3=$ severe. The four nasal total symptom score (4NTSS) was the sum of the scores for the individual symptoms. The total symptom score (5TSS) is the sum of the nasal symptom scores and the ocular symptom score.

Patient visits and follow-up visits were conducted as follows: visit 1 (day -21 -1): screening; visit 2 (day 0): randomization; visit 3 (day $15 \pm 3$ ): intermediate; and visit 4: closing (day $29 \pm 3$ ). The investigators examined patients' diary cards at each follow-up visit (visits 3 and 4) to check treatment compliance and provide any advice. Patient and investigator evaluations of the therapeutic response to treatment at 2 weeks (visit 3) and 4 weeks (visit 4) were also assessed. In these two follow-up visits, patients' and physicians' global evaluation of efficacy was scored numerically on a scale of 0 to 4 with $0=$ worsened, 1 = no change, 2 = slight improvement, 3 = good improvement, and $4=$ excellent improvement. Secondary parameters of efficacy included an overall evaluation of efficacy as assessed by the investigator and patient, mean daily symptom score (DSSmean), and the Pdmaxl index. The Pdmaxl was calculated as the percentage of days during the study for each patient when the score of the daily most severe symptom was $\leq 1$.

\section{Evaluation of safety}

Treatment safety and tolerability were evaluated according to the incidence and type of adverse events voluntarily reported in the patient's diary or reported as an answer to the investigator's question at each visit. Occurrence/disappearance date, severity and consequence, treatment-related actions, causal relationship with treatment, other suspicious drugs, and treatment of adverse events were included during the adverse event check.

\section{Statistical analysis}

It was estimated that 110 patients had to be included in each treatment group (for a total of 330 patients) in order to show the expected difference between active treatments and placebo of $20 \%$ in the main efficacy variable, considering a dropout rate of $20 \%$ and a protection level of 0.05 against type I random errors and of 0.2 against type II errors. Analysis of variance was used to compare treatment groups for the quantitative primary and secondary outcomes. In case of significant results, subsequent pairwise comparisons using a Bonferroni adjustment were made between the treatment groups.
For quantitative (efficacy and safety) variables, mean, median, standard deviation, and maximum and minimum values were calculated. Qualitative variables were expressed as relative frequencies. The Chi-square test was used for qualitative variables, and Fisher's test was used if the applicability conditions were not present. The Mantel-Haenszel chi-square test was performed if both variables lay on an ordinal scale. The analysis of both efficacy and safety was based on the intention-to-treat (ITT) group, which included all patients who were randomized and received at least one dose of the study medication. The incidence of adverse events was compared between treatment groups by using the chi-square test. All statistical analyses were two-tailed, with the significance level set at $p<0.05$. Statistical analyses were performed using SAS 9.1 .

\section{Results \\ Study population}

Patient disposition during the study is shown in Figure $\mathbf{1 .}$ A total of 429 patients were enrolled in the trial, 99 of which failed the initial screening test and were excluded. Reasons for screening failure included failure to meet the inclusion criteria and refusal to participate. Of the 330 patients who were randomized, 306 completed the study and 324 received at least one treatment dose, comprising the ITT population and were evaluated for safety. Reasons for withdrawal $(n=24)$ included unwillingness to continue, adverse event and use of prohibited drugs. At baseline, demographic data showed no differences between the relevant demographic and clinical characteristics (Table S1).

\section{Efficacy of treatments}

Figures 2 and 3 show the morning and evening 12-h reflective scores at baseline and at 2 and 4 weeks of treatment. All three groups including the two active groups and one placebo group showed a significant reduction in symptom scores in the morning and evening evaluations at 2 and 4 weeks. Both 5TSS $(p<0.001)$ and 4NTSS $(p<0.001)$ were significantly improved.

In the morning evaluations at 4 weeks, the rupatadine group showed significant reductions of $-63.67 \%$ and $-65.37 \%$ from baseline in 4TNSS and 5TSS, respectively. These values were significantly higher than the corresponding values in the placebo group $(-46.70 \%,-47.05 \%)$ and the bepotastine group $(-52.80 \%,-53.08 \%)(p<0.05)$. Compared to the placebo group, the bepotastine group showed reductions of $-52.8 \%$ and $-53.08 \%$ in 4 TNSS and 5TSS, respectively, but the intergroup differences were not significant (Figure 2 and Table S2).

In the evening evaluations at 4 weeks, there were significant reductions of 4 NTSS and 5TSS in the rupatadine group (-61.58\%, $p<0.05 ;-63.17 \%, p<0.01$, respectively) compared with those in the placebo group. There was no statistical difference in improvement compared to that in the bepotastine group. Compared to the placebo group, the bepotastine group did not show a significant reduction from baseline (Figure 3 and Table S3). 


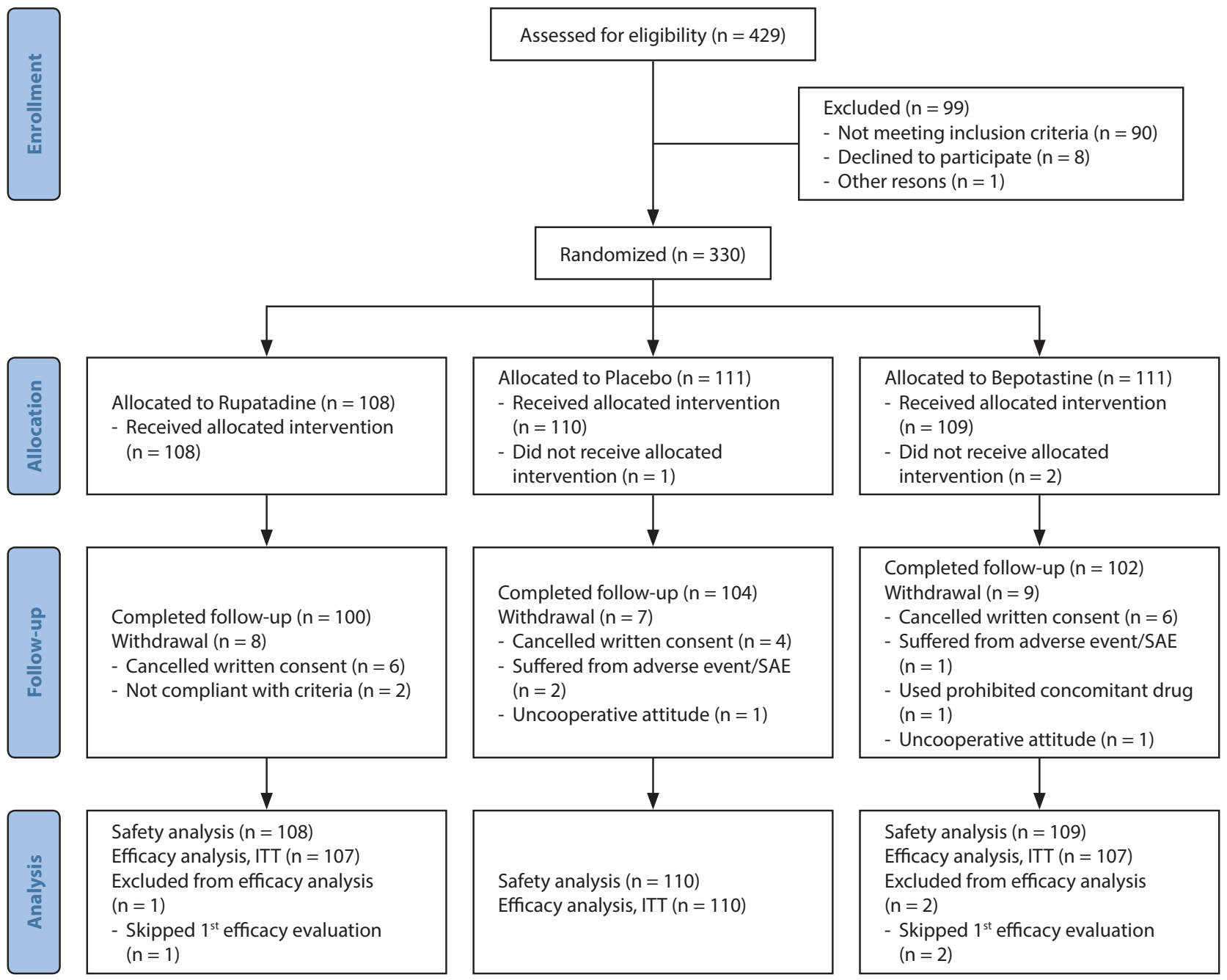

Figure 1. Flowchart showing the disposition of patients.

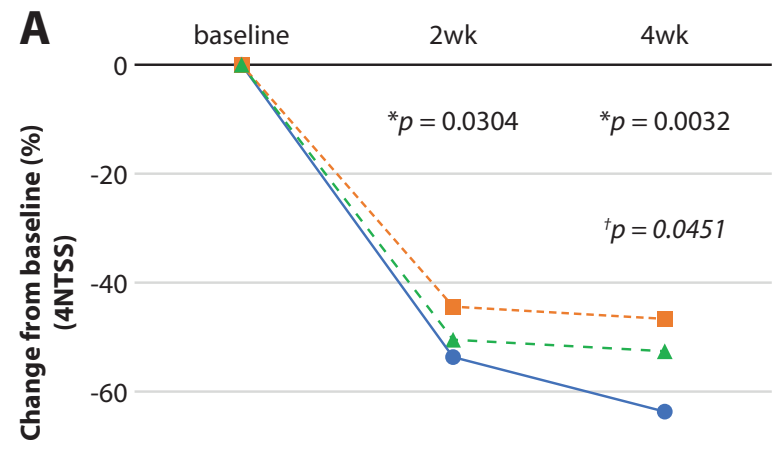

$-80$

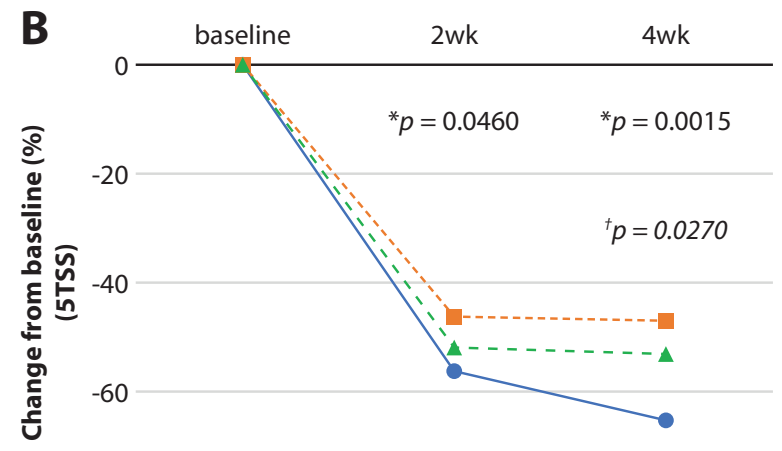

$-80$

Rupatadine - - - Placebo - - - Bepotastine

Figure 2. Changes from baseline of morning (12-h reflective) nasal total symptom score (4NTSS) (A) and total symptom score (5TSS) (B). * refers to p-value of rupatadine versus placebo. ${ }^{\dagger}$ refers to $\mathbf{p}$-value of bepotastine versus placebo. 


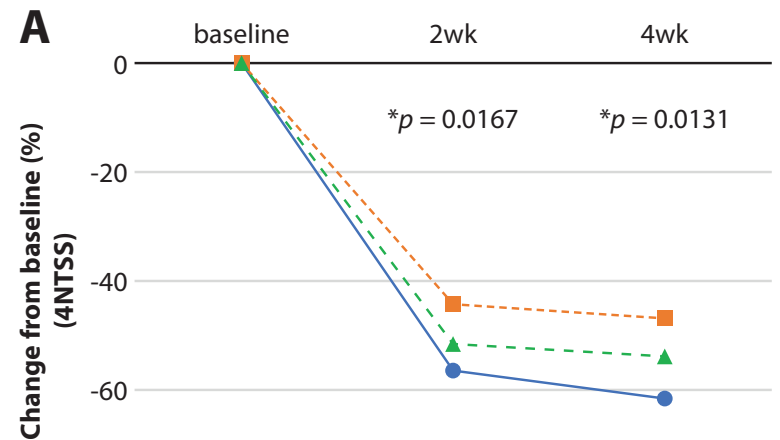

$-80$
B

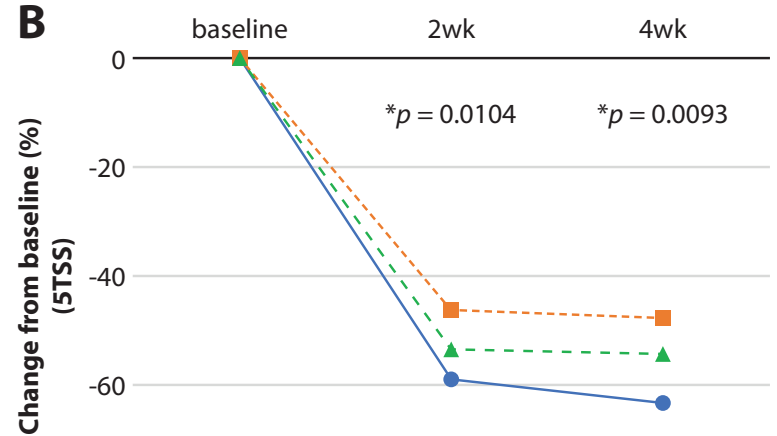

$-80$

$\Delta-$ Bepotastine

Figure 3. Changes from baseline of evening (12-h reflective) nasal total symptom score (4NTSS) (A) and total symptom score (5TSS) (B). * refers to $\mathrm{p}$-value of rupatadine versus placebo.

The DSSmean during the study period was compared between the rupatadine and bepotastine groups. The difference in sneezing $(p=0.0158)$ and ocular itching $(p=0.0483)$ scores was statistically significant, whereas the differences in rhinorrhea ( $p=0.0971)$, nasal congestion $(p=0.0728)$, and nasal itching $(p=0.1271)$ scores showed a tendency toward superiority but were not statistically significant. Only the rupatadine group did significantly better than the placebo group in terms of Pdmax1 (percentage of days during the study period when the maximum daily score was 0 to 1 ) mean values (reflective): placebo $=41.2 \%$; bepotastine $=45.3 \%$; and rupatadine $=51.7 \%(p=0.034)$ (secondary endpoints of efficacy) (Table 1)

When the investigator's overall evaluation of efficacy at 4 weeks was compared among the three groups (Table 2), no significant difference was noted between the rupatadine

Table 1. 12-h reflective DSSmean and PDmax1.

\begin{tabular}{|lcccccc|}
\hline & $\begin{array}{c}\text { Rupatadine } \\
(\mathbf{N}=107)\end{array}$ & $\begin{array}{c}\text { Placebo } \\
(\mathbf{N}=110)\end{array}$ & $\begin{array}{c}\text { Bepotastine } \\
(\mathbf{N}=107)\end{array}$ & $p_{\text {-value }}^{*}$ & $p$-value & $p$-value - $^{\dagger+}$ \\
\hline Sneezing & $0.60 \pm 0.55$ & $0.80 \pm 0.65$ & $0.65 \pm 0.56$ & 0.0158 & 0.4789 & 0.061 \\
\hline Rhinorrhea & $0.92 \pm 0.57$ & $1.05 \pm 0.65$ & $0.99 \pm 0.60$ & 0.0971 & 0.3905 & 0.435 \\
\hline Nasal congestion & $1.04 \pm 0.70$ & $1.23 \pm 0.79$ & $1.21 \pm 0.67$ & 0.0728 & 0.0762 & 0.921 \\
\hline Nasal itching & $0.61 \pm 0.56$ & $0.74 \pm 0.64$ & $0.67 \pm 0.59$ & 0.1271 & 0.4381 & 0.387 \\
\hline Ocular itching & $0.39 \pm 0.49$ & $0.54 \pm 0.61$ & $0.44 \pm 0.53$ & 0.0483 & 0.4253 & 0.165 \\
\hline PDmax1 (\%) & $51.69 \pm 36.09$ & $41.24 \pm 35.89$ & $45.26 \pm 37.17$ & 0.0337 & 0.2005 & 0.423 \\
\hline
\end{tabular}

DSSmean, mean daily symptom score during the study period; PDmaxl, percentage of days during the study period when the maximum daily score was from 0 to 1

* $p$ values refer to rupatadine versus placebo.

${ }^{\dagger} p$ values refer to rupatadine versus bepotastine.

${ }^{\dagger \dagger} p$ values refer to bepotastine versus placebo.

Table 2. Overall evaluation of efficacy at 4 weeks.

\begin{tabular}{|c|c|c|c|c|c|c|c|}
\hline & & $\begin{array}{l}\text { Rupatadine } \\
(\mathbf{N}=104)\end{array}$ & $\begin{array}{c}\text { Placebo } \\
(\mathbf{N}=108)\end{array}$ & $\begin{array}{l}\text { Bepotastine } \\
(\mathbf{N}=107)\end{array}$ & \multirow{2}{*}{$p$-value ${ }^{*}$} & \multirow{2}{*}{$p$-value ${ }^{\dagger}$} & \multirow{2}{*}{$p$-value ${ }^{\dagger \dagger}$} \\
\hline & & N (\%) & N (\%) & N (\%) & & & \\
\hline \multirow[t]{6}{*}{ Investigator } & Worse & $1(0.9)$ & $2(1.9)$ & $2(1.9)$ & 0.0794 & 0.4849 & 0.2813 \\
\hline & No change & $35(33.7)$ & $53(49.1)$ & $41(38.3)$ & & & \\
\hline & Slight & $35(33.7)$ & $33(30.6)$ & $40(37.4)$ & & & \\
\hline & Good & $29(27.9)$ & $16(14.8)$ & $23(21.5)$ & & & \\
\hline & Excellent & $4(3.8)$ & $4(3.7)$ & $1(0.9)$ & & & \\
\hline & Total sum & $104(100.00)$ & $108(100.00)$ & $107(100.00)$ & & & \\
\hline
\end{tabular}


Table 2. (Continued)

\begin{tabular}{|c|c|c|c|c|c|c|c|}
\hline & & $\begin{array}{l}\text { Rupatadine } \\
(\mathrm{N}=104)\end{array}$ & $\begin{array}{c}\text { Placebo } \\
(\mathrm{N}=108)\end{array}$ & $\begin{array}{c}\text { Bepotastine } \\
(\mathrm{N}=106)\end{array}$ & \multirow[t]{2}{*}{$p$-value ${ }^{*}$} & \multirow[t]{2}{*}{$p$-value ${ }^{\dagger}$} & \multirow[t]{2}{*}{$p$-value ${ }^{\dagger+}$} \\
\hline & & N (\%) & N (\%) & N (\%) & & & \\
\hline \multirow[t]{6}{*}{ Subject } & Worse & $1(0.9)$ & $6(5.6)$ & $6(5.7)$ & 0.0024 & 0.0140 & 0.7346 \\
\hline & No change & $30(28.8)$ & $50(46.3)$ & $38(35.8)$ & & & \\
\hline & Slight & $40(38.5)$ & $38(35.2)$ & $47(44.3)$ & & & \\
\hline & Good & $26(25.0)$ & $10(9.3)$ & $10(9.4)$ & & & \\
\hline & Excellent & $7(6.8)$ & $4(3.7)$ & $5(4.7)$ & & & \\
\hline & Total sum & $104(100.00)$ & $108(100.00)$ & $106(100.00)$ & & & \\
\hline
\end{tabular}

${ }^{*} p$ values for rupatadine and placebo were calculated using Fischer's exact test or Chi-square test.

${ }^{\dagger} p$ values for rupatadine and bepotastine were calculated using Fischer's exact test or Chi-square test.

${ }^{i t} p$ values for bepotastine and placebo were calculated using Fischer's exact test or Chi-square test.

and placebo groups $(p=0.08)$ and between the rupatadine and bepotastine groups $(p=0.48)$. However, compared to the placebo group, the rupatadine group showed a superior tendency in the improvement category. Self-evaluations of patients in the rupatadine group showed a statistically significant improvement compared to those of patients in the placebo group $(p=0.002)$ and the bepotastine group $(p=0.014)$.

\section{Safety}

The adverse event rates regardless of a causal relationship with treatment were $25.93 \%$ (28/108 subjects, 65 cases) in the rupatadine group, $19.09 \%$ (21/110 subjects, 37 cases) in the placebo group, and $28.44 \%$ (31/109 subjects, 74 cases) in the bepotastine group (Table 3). Most common adverse events were headache, somnolence and nasopharyngitis.

Table 3. Summary of adverse events.

\begin{tabular}{|c|c|c|c|c|c|c|c|c|}
\hline & & \multicolumn{2}{|c|}{ Rupatadine ( $N=108)$} & \multicolumn{2}{|c|}{ Placebo $(\mathbf{N}=110)$} & \multicolumn{2}{|c|}{ Bepotastine $(\mathrm{N}=109)$} & \multirow{2}{*}{$p$-value } \\
\hline & & Cases & Rate n (\%) & Cases & Rate n (\%) & Cases & Rate n (\%) & \\
\hline \multirow[t]{7}{*}{$\mathrm{AE}$} & Headache & 8 & $7(6.48)$ & 8 & $5(4.55)$ & 13 & $10(9.17)$ & \\
\hline & Somnolence & 11 & $10(9.26)$ & 1 & $1(0.91)$ & 7 & $7(6.42)$ & \\
\hline & GI disorder & 16 & $6(5.56)$ & 5 & $3(2.73)$ & 18 & $10(9.17)$ & \\
\hline & Nasopharyngitis & 5 & $5(4.63)$ & 4 & $4(3.64)$ & 5 & $5(4.59)$ & \\
\hline & Dry nose, eye & 1 & $1(0.93)$ & 0 & $0(0.00)$ & 2 & $2(1.83)$ & \\
\hline & Others & 24 & - & 19 & - & 29 & - & \\
\hline & Total & 65 & $28(25.9)$ & 37 & 19.1 & 74 & 28.4 & 0.2496 \\
\hline \multirow[t]{7}{*}{$\mathrm{ADR}$} & Headache & 2 & $2(1.85)$ & 1 & $1(0.91)$ & 2 & $2(1.83)$ & \\
\hline & Somnolence & 7 & $7(6.48)$ & 1 & $1(0.91)$ & 4 & $4(3.67)$ & \\
\hline & GI disorder & 0 & $0(0.00)$ & 0 & $0(0.00)$ & 4 & $3(2.75)$ & \\
\hline & Nasopharyngitis & 0 & $0(0.00)$ & 0 & $0(0.00)$ & 1 & $1(0.92)$ & \\
\hline & Dry nose, eye & 1 & $1(0.93)$ & 0 & $0(0.00)$ & 2 & $2(1.83)$ & \\
\hline & Others & 5 & - & 4 & - & 6 & - & \\
\hline & Total & 15 & $11(10.2)$ & 6 & $5(4.6)$ & 19 & $11(10.1)$ & 0.2216 \\
\hline \multirow[t]{4}{*}{ SAE } & Meningitis & 0 & $0(0.00)$ & 0 & $0(0.00)$ & 1 & $1(0.92)$ & \\
\hline & Total & 0 & $0(0.00)$ & 0 & $0(0.00)$ & 1 & $1(0.92)$ & \\
\hline & SADR & 0 & 0 & 0 & 0 & 0 & 0 & \\
\hline & Withdrawn & 0 & 0 & 2 & 1.8 & 1 & 0.9 & 0.7757 \\
\hline
\end{tabular}

$\mathrm{AE}$, adverse event; ADR, adverse drug reaction; SAE, serious adverse event; SADR, serious adverse drug reaction ${ }^{\star} p$ values were calculated using Fischer's exact test or Chi-square test 
Analysis of laboratory tests and ECG parameters (QTc interval) did not show any clinically relevant findings in the groups.

\section{Discussion}

Rupatadine is an $\mathrm{N}$-alkyl pyridinium derivative that is believed to have dual inhibitory effects on two important mediators of allergy, histamine (H1) and PAF. ${ }^{6}$ Clinical studies have been previously conducted to evaluate the efficacy and safety of rupatadine for AR.-9,12-16 In a recent systematic analysis of randomized, double-blind, placebo-controlled studies that included 10 trials with a total of 2573 patients, ${ }^{9}$ rupatadine treatment caused a greater reduction of nasal symptoms than that achieved with the placebo. We designed and executed a bridging study to demonstrate the efficacy of once-daily administration of rupatadine in relieving PAR symptoms in Korean patients. We also compared the efficacy of rupatadine with that of bepotastine, a second-generation antihistamine.

The results of our study showed that rupatadine treatment resulted in a greater reduction in the severity of nasal and ocular symptoms than that achieved with the placebo, confirming the results of previous studies conducted in the Western hemisphere. ${ }^{7,14-16}$ The primary outcome parameter was a reduction in morning and evening symptoms after 4 weeks of treatment. We evaluated morning and evening symptoms separately because symptoms of AR show circadian variation, with worsened symptoms in the morning. ${ }^{17}$ Compared to the placebo, rupatadine was superior in terms of its effects on both morning and evening symptoms. Therefore, although ethnic variation may alter a pharmaceutical compound's safety, efficacy, or dose response, our results showed that ethnicity was not a factor affecting the effectiveness and safety of rupatadine.

Previous studies comparing the efficacy of rupatadine with those of other antihistamines have shown no difference in efficacy between rupatadine cetirizine, ebastine, and loratadine, ${ }^{7,14-16}$ whereas the efficacy of rupatadine was higher than that of levocetirizine. ${ }^{14}$ We chose bepotastine as the reference drug because it has been proven to be a safe and effective second-generation $\mathrm{H} 1$-antihistamine ${ }^{18}$ and it had the largest market share in Korea during the design of our study. Compared with bepotastine, rupatadine showed greater reduction in the morning symptoms at 4 weeks. The mean daily symptom scores showed a tendency for improvement in nasal obstruction in the rupatadine group ( $p=0.0762)$.

PAF is a mediator produced by inflammatory cells in response to allergic stimuli ${ }^{19}$ and is associated with increased vascular permeability, eosinophil chemoattraction, and airway hyper-responsiveness. ${ }^{20}$ PAF and histamine are known to complement each other in vivo; histamine is a mediator of the early response, being released from preformed reservoirs in mast cells, whereas PAF is mainly synthesized de novo. ${ }^{4}$ Furthermore, each of these mediators is able to promote the release of the other in numerous target cells. Therefore, a dual antagonist of histamine and PAF, such as rupatadine, can inhibit the early and late reactions of AR more effectively. The reason for the difference in the morning symptoms might be related to the diurnal variation in allergic symptoms, whereby the severity of all major AR symptoms, including runny nose, sneezing, and nasal congestion, is typically more severe in the morning. ${ }^{21}$ Collectively, the results of our study confirm the effectiveness of rupatadine in the treatment of PAR in Koreans and its superiority over bepotastine in controlling morning symptoms.

Regarding safety issues, no statistically significant difference was noted among the three groups. The most common adverse event was somnolence. In the rupatadine and bepotastine groups, the rates of somnolence were $9.2 \%$ and $6.4 \%$, respectively, whereas that in the placebo group was only $0.9 \%$. These results were consistent with those published previously, whereby a $10 \%$ incidence of somnolence was reported during 4 weeks of rupatadine treatment for PAR. ${ }^{15}$

\section{Conclusion}

The results of the present multicenter, double-blinded, randomized, placebo-controlled, bridging study show that rupatadine is a safe and effective pharmacological option for Korean patients with PAR.

\section{Acknowledgements}

The study was sponsored by Ahn-Gook Pharmaceuticals Co., Ltd. Tae-Bin Won and Hyung Gu Kim contributed equally to this work.

\section{References}

1. Rhee CS, Wee JH, Ahn JC, Lee WH, Tan KL, Ahn S, et al. Prevalence, risk factors and comorbidities of allergic rhinitis in South Korea: The Fifth Korea National Health and Nutrition Examination Survey. Am J Rhinol Allergy. 2014;28:e107-14.

2. Meltzer EO. Allergic Rhinitis: Burden of Illness, Quality of Life, Comorbidities, and Control. Immunol Allergy Clin North Am. 2016;36: 235-48.

3. Simons FE, Simons KJ. Histamine and H1-antihistamines: celebrating a century of progress. J Allergy Clin Immunol. 2011;128:1139-50 e4.

4. Baraniuk JN. Pathogenesis of allergic rhinitis. J Allergy Clin Immunol. 1997;99:S763-72.

5. Frieri M. Inflammatory issues in allergic rhinitis and asthma. Allergy Asthma Proc. 2005;26:163-9.

6. Merlos M, Giral M, Balsa D, Ferrando R, Queralt M, Puigdemont A, et al. Rupatadine, a new potent, orally active dual antagonist of histamine and platelet-activating factor (PAF). J Pharmacol Exp Ther. 1997;280:114-21.

7. Marmouz F, Giralt J, Izquierdo I. Morning and evening efficacy evaluation of rupatadine (10 and $20 \mathrm{mg}$ ), compared with cetirizine $10 \mathrm{mg}$ in perennial allergic rhinitis: a randomized, double-blind, placebo-controlled trial. J Asthma Allergy. 2011;4:27-35.

8. Dakhale G, Tathod Y, Patel S, Pimpalkhute S, Raghute L, Khamkar A. Comparison of efficacy, safety, and cost-effectiveness of rupatadine and olopatadine in patients of allergic rhinitis: A prospective, randomized, double-blind, parallel group study. J Pharmacol Pharmacother. 2016;7: 171-6.

9. Compalati E, Canonica GW. Efficacy and safety of rupatadine for allergic rhino-conjunctivitis: a systematic review of randomized, double-blind, placebo-controlled studies with meta-analysis. Curr Med Res Opin. 2013; 29:1539-51.

10. Ramamoorthy A, Pacanowski MA, Bull J, Zhang L. Racial/ethnic differences in drug disposition and response: review of recently approved drugs. Clin Pharmacol Ther. 2015;97:263-73.

11. Lyseng-Williamson KA. Oral bepotastine: in allergic disorders. Drugs. 2010;70:1579-91.

12. Maiti R, Jaida J, Rahman J, Gaddam R, Palani A. Olopatadine hydrochloride and rupatadine fumarate in seasonal allergic rhinitis: A comparative study of efficacy and safety. J Pharmacol Pharmacother. 2011; 2:270-6. 
13. Maiti R, Rahman J, Jaida J, Allala U, Palani A. Rupatadine and levocetirizine for seasonal allergic rhinitis: a comparative study of efficacy and safety. Arch Otolaryngol Head Neck Surg. 2010;136:796-800.

14. Lukat K, Rivas P, Roger A, Kowalski M, Botzen U, Wessel F, et al. A direct comparison of efficacy between desloratadine and rupatadine in seasonal allergic rhinoconjunctivitis: a randomized, double-blind, placebo-controlled study. J Asthma Allergy. 2013;6:31-9.

15. Kowalski M, Jurkiewicz D, Kruszewski J, Nowak D, Zietkowski Z, Špičaková $\mathrm{M}$, et al. Rupatadine 10 and $20 \mathrm{mg}$ are effective and safe in the treatment of perennial allergic rhinitis after 4 weeks of treatment: a randomized, double-blind, controlled trial with loratadine and placebo. Therapy. 2009;6:417-25.

16. Molina M, Pinto E, Cisteró A, Martínez R, Montero J, García-González $\mathrm{J}$, et al. Rupatadine $10 \mathrm{mg}$ in adolescent and adult symptom relief of perennial allergic rhinitis. Therapy. 2010;7:429-36.
17. Nakao A, Nakamura Y, Shibata S. The circadian clock functions as a potent regulator of allergic reaction. Allergy. 2015;70:467-73.

18. Baba S, Takasaka T, Baba K. Long-term treatment of TAU-284 (bepotastine besilate) on perennial allergic rhinitis. Rinsho Iyaku. 1997;13:1137-45.

19. Kajiwara N, Sasaki T, Bradding P, Cruse G, Sagara H, Ohmori K, et al Activation of human mast cells through the platelet-activating factor receptor. J Allergy Clin Immunol. 2010;125:1137-45 e6.

20. Mullol J, Bousquet J, Bachert C, Canonica WG, Gimenez-Arnau A, Kowalski ML, et al. Rupatadine in allergic rhinitis and chronic urticaria. Allergy. 2008;63 Suppl 87:5-28.

21. Haye R, Hoye K, Berg O, Frones S, Odegard T. Morning versus evening dosing of desloratadine in seasonal allergic rhinitis: a randomized controlled study [ISRCTN23032971]. Clin Mol Allergy. 2005;3:3.

Table S1. Demographic data of subjects.

\begin{tabular}{|c|c|c|c|c|}
\hline & $\begin{array}{l}\text { Rupatadine } \\
(\mathbf{N}=\mathbf{1 0 8})\end{array}$ & $\begin{array}{l}\text { Placebo } \\
(\mathrm{N}=110)\end{array}$ & $\begin{array}{c}\text { Bepotastine } \\
(\mathbf{N}=109)\end{array}$ & $p$-value \\
\hline Sex (male, \%) & 46.30 & 45.45 & 43.12 & $0.8878^{*}$ \\
\hline Age (years) & $28.6 \pm 10.0$ & $28.1 \pm 9.2$ & $30.7 \pm 9.1$ & $0.1091^{\dagger}$ \\
\hline Disease period & $81.9 \pm 63.9$ & $93.7 \pm 82.0$ & $70.0 \pm 55.1$ & $0.4480^{\dagger}$ \\
\hline 5TSS (baseline mean) & $8.61 \pm 2.20$ & $8.05 \pm 2.18$ & $8.61 \pm 2.58$ & $0.1397^{\dagger \dagger}$ \\
\hline 4NTSS (baseline mean) & $7.32 \pm 1.88$ & $6.95 \pm 1.73$ & $7.35 \pm 2.09$ & $0.0643^{\dagger 1}$ \\
\hline
\end{tabular}

5TSS, total symptom score calculated by adding scores for five symptoms (rhinorrhea, sneezing, nasal itching, nasal obstruction, and conjunctival itching); 4NTSS, total nasal symptom score calculated by adding scores for four symptoms (rhinorrhea, sneezing, nasal itching, and nasal obstruction). No significant differences were found between treatment groups.

${ }^{*} p$ values were calculated using Pearson's chi-square test.

${ }^{\dagger} p$ values were calculated using ANOVA.

${ }^{\dagger \dagger} p$ values refers to rupatadine versus placebo.

Table S2. Summary of morning (12-h reflective) total symptom score (5TSS) and nasal total symptom score (4NTSS).

\begin{tabular}{|c|c|c|c|c|c|c|c|c|c|c|}
\hline & & \multicolumn{2}{|c|}{$\begin{array}{l}\text { Rupatadine } \\
(\mathbf{N}=107)\end{array}$} & \multicolumn{2}{|c|}{$\begin{array}{l}\text { Placebo } \\
(\mathbf{N}=110)\end{array}$} & \multicolumn{2}{|c|}{$\begin{array}{c}\text { Bepotastine } \\
(\mathbf{N}=107)\end{array}$} & \multirow{2}{*}{$p$-value* } & \multirow{2}{*}{$p$-value ${ }^{*}$} & \multirow{2}{*}{$p$-value $e^{\dagger \dagger}$} \\
\hline & & mean & STD & mean & STD & mean & STD & & & \\
\hline \multirow[t]{7}{*}{ 4NTSS } & Baseline & 7.32 & 1.88 & 6.95 & 1.73 & 7.35 & 2.09 & 0.1397 & 0.9180 & 0.1351 \\
\hline & 2 weeks & 3.25 & 2.54 & 3.79 & 2.80 & 3.47 & 2.56 & 0.1396 & 0.5385 & 0.3758 \\
\hline & difference from baseline at 2 weeks & -4.07 & 3.09 & -3.16 & 3.01 & -3.88 & 3.17 & 0.0304 & 0.6626 & 0.0895 \\
\hline & $\%$ change from baseline at 2 weeks & -53.62 & 36.77 & -44.46 & 39.74 & -50.48 & 36.51 & 0.0304 & 0.6626 & 0.0895 \\
\hline & 4 weeks & 2.58 & 2.74 & 3.67 & 3.31 & 3.35 & 3.03 & 0.0086 & 0.0537 & 0.4496 \\
\hline & difference from baseline at 4 weeks & -4.74 & 3.24 & -3.28 & 3.42 & -4.00 & 3.47 & 0.0015 & 0.1091 & 0.1259 \\
\hline & $\%$ change from baseline at 4 weeks & -63.67 & 36.41 & -46.70 & 46.75 & -52.80 & 42.23 & 0.0032 & 0.0451 & 0.3150 \\
\hline \multirow[t]{7}{*}{$5 \mathrm{TSS}$} & Baseline & 8.61 & 2.20 & 8.05 & 2.18 & 8.61 & 2.58 & 0.0643 & 1.0000 & 0.0897 \\
\hline & 2 weeks & 3.64 & 2.94 & 4.27 & 3.28 & 3.86 & 2.89 & 0.1392 & 0.5904 & 0.3266 \\
\hline & difference from baseline at 2 weeks & -4.96 & 3.48 & -3.78 & 3.41 & -4.75 & 3.79 & 0.0124 & 0.6661 & 0.0496 \\
\hline & $\%$ change from baseline at 2 weeks & -56.39 & 34.43 & -46.36 & 38.97 & -52.07 & 37.18 & 0.0460 & 0.3782 & 0.2716 \\
\hline & 4 weeks & 2.92 & 3.19 & 4.20 & 3.90 & 3.84 & 3.62 & 0.0085 & 0.0485 & 0.4837 \\
\hline & difference from baseline at 4 weeks & -5.69 & 3.67 & -3.85 & 4.04 & -4.77 & 4.24 & 0.0006 & 0.0894 & 0.1062 \\
\hline & $\%$ change from baseline at 4 weeks & -65.37 & 35.35 & -47.05 & 47.85 & -53.08 & 44.79 & 0.0015 & 0.0270 & 0.3393 \\
\hline
\end{tabular}

STD, standard deviation

${ }^{*} p$ values refer to rupatadine versus placebo.

${ }^{\dagger} p$ values refer to rupatadine versus bepotastine.

${ }^{\dagger \dagger} p$ values refer to bepotastine versus placebo. 
Table S3. Summary of evening (12-h reflective) total symptom score (5TSS) and nasal total symptom score (4NTSS)

\begin{tabular}{|c|c|c|c|c|c|c|c|c|c|c|}
\hline & & \multicolumn{2}{|c|}{$\begin{array}{c}\text { Rupatadine } \\
(\mathrm{N}=107)\end{array}$} & \multicolumn{2}{|c|}{$\begin{array}{l}\text { Placebo } \\
(\mathrm{N}=110)\end{array}$} & \multicolumn{2}{|c|}{$\begin{array}{c}\text { Bepotastine } \\
(\mathbf{N}=107)\end{array}$} & \multirow{2}{*}{$p$-value } & \multirow{2}{*}{$p$-value ${ }^{\dagger}$} & \multirow{2}{*}{$p$-value ${ }^{\dagger \dagger}$} \\
\hline & & mean & STD & mean & STD & mean & STD & & & \\
\hline \multirow[t]{7}{*}{ 4NTSS } & Baseline & 7.32 & 1.88 & 6.95 & 1.73 & 7.35 & 2.09 & 0.1397 & 0.9180 & 0.1351 \\
\hline & 2 weeks & 3.08 & 2.38 & 3.78 & 2.74 & 3.38 & 2.53 & 0.0479 & 0.3743 & 0.2703 \\
\hline & difference from baseline at 2 weeks & -4.23 & 2.89 & -3.14 & 3.00 & -3.96 & 3.14 & 0.0067 & 0.5122 & 0.0496 \\
\hline & $\%$ change from baseline at 2 weeks & -56.47 & 33.93 & -44.20 & 40.48 & -51.58 & 36.17 & 0.0167 & 0.3087 & 0.1594 \\
\hline & 4 weeks & 2.76 & 2.88 & 3.65 & 3.28 & 3.21 & 3.01 & 0.0346 & 0.2568 & 0.3095 \\
\hline & difference from baseline at 4 weeks & -4.56 & 3.26 & -3.27 & 3.37 & -4.13 & 3.61 & 0.0046 & 0.3619 & 0.0703 \\
\hline & $\%$ change from baseline at 4 weeks & -61.58 & 38.67 & -46.75 & 47.98 & -53.81 & 43.75 & 0.0131 & 0.1702 & 0.2600 \\
\hline \multirow[t]{7}{*}{5 TSS } & Baseline & 8.61 & 2.20 & 8.05 & 2.18 & 8.61 & 2.58 & 0.0643 & 1.0000 & 0.0897 \\
\hline & 2 weeks & 3.44 & 2.71 & 4.21 & 3.20 & 3.77 & 2.99 & 0.0573 & 0.4029 & 0.2925 \\
\hline & difference from baseline at 2 weeks & -5.17 & 3.27 & -3.80 & 3.43 & -4.84 & 3.80 & 0.0030 & 0.5006 & 0.0355 \\
\hline & $\%$ change from baseline at 2 weeks & -58.97 & 32.20 & -46.28 & 39.61 & -53.43 & 37.85 & 0.0104 & 0.2500 & 0.1767 \\
\hline & 4 weeks & 3.12 & 3.32 & 4.17 & 3.93 & 3.70 & 3.56 & 0.0363 & 0.2199 & 0.3644 \\
\hline & difference from baseline at 4 weeks & -5.49 & 3.70 & -3.84 & 3.97 & -4.91 & 4.34 & 0.0019 & 0.2941 & 0.0617 \\
\hline & $\%$ change from baseline at 4 weeks & -63.17 & 38.59 & -47.58 & 48.21 & -54.28 & 45.67 & 0.0093 & 0.1254 & 0.2960 \\
\hline
\end{tabular}

${ }^{*} p$ values refer to rupatadine versus placebo.

${ }^{\dagger} p$ values refer to rupatadine versus bepotastine.

${ }^{\dagger \dagger} p$ values refer to bepotastine versus placebo. 